\title{
Ege Üniversitesi Hastanesi veri tabanındaki kanser olgularının epidemiyolojik ve genel sağ kalım özellikleri
}

\section{Epidemiological and overall survival characteristics of cancer patients in Ege University Hospital database}

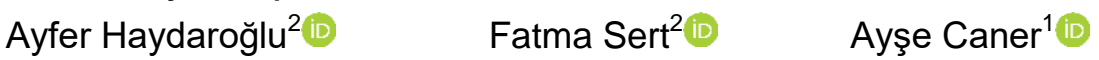 \\ ${ }^{1}$ Ege Üniversitesi Tıp Fakültesi, Kanserle Savaş Araştırma ve Uygulama Merkezi (EÜKAM), İzmir, Türkiye \\ ${ }^{2}$ Ege Üniversitesi Tıp Fakültesi, Radyasyon Onkolojisi Anabilim Dalı, İzmir, Türkiye
}

Öz

Amaç: Ege Üniversitesi Hastanesi $(E U ̈ H)$ veri tabanındaki kanser olgularının epidemiyolojik ve genel sağ kalım (GSK) özelliklerini istatistiksel açıdan değerlendirmektir.

Gereç ve Yöntem: Türkiye'de ilk kez aktif kanser kayıtçılığı EÜ Kanser Araştırma Merkezi (EÜKAM) tarafından 1992'de başlatılmıştır. CANREG özel bilgisayar programına kaydedilen veriler DSÖ ve SEER sistemleri temelinde gruplanarak analizler yapılmıştır. İstatistik analizlerde Ki-kare, General Linear Model (GLM), Kaplan Meier sağ kalım analizleri uygulanmıştır. Kaplan Meier sağ kalım analizinde Log Rank (Mantel-Cox), Breslow (Generalized Wilcoxon) ve Tarone-Ware istatistikleri kullanılmıştır. İstatistik analizlerde $p<0,05$ istatistiksel olarak anlamlı kabul edilmiştir.

Bulgular: EÜKAM tarafından 1992-2017 arasında, 25 yılda 117139 kanser kaydı yapılmış olup bu çalışma içine cilt kanserleri hariç 107238 kanser verisi esas alınmıştır. Olguların \%52,8'i erkek, \%47,8'i kadındır. Olguların yaş ortalaması $54,87 \pm 0,62$ olup erkeklerde $60-69$ yaş grubunda, kadınlarda ise 50 59 yaş grubunda en sık görülmektedir $(p<0,0001)$. Organ tutulumuna göre en sık görülen ilk üç tümör akciğer, meme ve tiroit kanseridir. Kadınlarda sırasıyla en sık meme, tiroit ve korpus uteri, erkeklerde ise akciğer, prostat ve hematolojik kanserlerdir. Yıllara ve organlara göre kanser görülme oranlarındaki doğrusal artış dikkat çekicidir $(p<0,0001)$. Kadın olgular en fazla $(\% 41,8)$ lokal evrede, erkekler ise metastatik dönemde $(\% 38,7)$ tanı almışlardır. Kadınlar anlamlı olarak daha erken evrede tanı almaktadır $(p<0,001)$. Cinsiyetlere göre 10 yıllık GSK erkeklerde $\% 36,6$, kadınlarda ise $\% 60,5$ olup kadın olgularımız daha uzun sağ kalıma sahiptir $(p=0,0001)$. Organlara göre 10 yıllık GSK tiroit ve meme kanserlerinde $(\% 92,4$ ve \%73,3) daha iyi, akciğer kanserlerinde ise en kötü $(\% 9,4)$ olduğu görülmüştür ( $p=0,0001)$.

Sonuç: Çalışmamızda erkeklerin kadınlara göre sayıca daha fazla ve daha ileri yaşlarda olduğu, kadınların ise erkeklere göre daha erken evrede tanı aldığı belirlenmiştir. Sağ kalımın tiroit ve meme kanserinde daha iyi, akciğer kanserlerinde ise en kötü olduğu görülmüştür. Olguların cinsiyetlerine göre GSK'leri incelendiğinde kadınların daha uzun sağ kalıma sahip olmaları dikkat çekicidir.

Anahtar Sözcükler: Kanser, epidemiyoloji, genel sağ kalım.

\begin{abstract}
Aim: To evaluate the epidemiological and overall survival (OS) characteristics of the patients from Ege University Hospital (EUH) cancer database.

Materials and Methods: The active cancer registry was launched in Ege University Cancer Research Center (EUCRC) as a first center in 1992. The data recorded in CANREG, which is special computer program, were grouped on the basis of WHO and SEER systems and analyzes were performed. In statistical analysis, chi-square, General Linear Model (GLM), and Kaplan-Meier survival curves were used. Log-Rank (Mantel-Cox), Breslow (Generalized Wilcoxon), and Tarone-Ware statistics were applied for survival analysis. $p<0.05$ was accepted statistically significant.
\end{abstract}

\footnotetext{
Yazışma Adresi: Ayfer Haydaroğlu

Ege Üniversitesi Tıp Fakültesi, Radyasyon Onkolojisi

Anabilim Dalı, İzmir, Türkiye

E-mail: haydaroglua@gmail.com
} 
Results: Between 1992 and 2017, 117259 cancer patients were registered by EUCRC within these 25 years. After excluding skin cancers, the data of 107238 remained cancer patients were included in this study. Male and women rates were $52.8 \%$ and $47.8 \%$, respectively. The mean age of the patients was $54.87 \pm 0.62$ and it was seen most frequently in the 60-69 age group in males and in the 50-59 age group in females $(p<0.001)$. The three most common tumors according to organ involvement are lung, breast and thyroid cancer. The most common cancer sites are breast, thyroid and corpus uteri cancers for women and lung, prostate and hematological cancers are for men. The linear increase in cancer incidence rates by years and organs is remarkable $(p<0.001)$. Most of the female patients $(41.8 \%)$ were diagnosed at the local stage and the males were diagnosed at the metastatic period (38.7\%). Women were diagnosed at a significantly earlier stage $(p<0.001)$. 10 -year OS rates were $36.6 \%$ for males and $60.5 \%$ for females. It was seen that female patients had statistically significant longer survival than male patients $(p<0.001)$. when we compared the 10-year OS rates according to primary organ, 10-year OS rates was found to be better in thyroid and breast cancers (92.4\% and 73.3\%), and the worst was in lung cancers (9.4\%).

Conclusion: In our study, it was shown that male cancer patients were more than females, and older than females. Additionally, female patients were diagnosed at earlier stages than males. Better OS rates were seen in thyroid and breast cancers, and the worst OS rate was in lung cancers.

Keywords: Cancer, epidemiology, overall survival.

\section{Giriş}

Kanser insidansında yıllara göre değerlendirme yapıldığında tüm global istatistiklerde bir artış olduğu görülmektedir (1, 2). Amerikan Kanser Derneği tarafından UICC ve WHO iş birliği ile yayınlanan Kanser Atlasına göre bazı ülkelerde 75 yaş öncesinde kanser gelişme riskinin \%35'e yaklaştığı belirtilmektedir. Tüm yeni kanser vakalarının yaklaşık yarısı ve tüm kanser ölümlerinin yarıdan biraz fazlası Asya'da gerçekleşmekte ve küresel yükün dörtte biri Çin'de ortaya çıkmaktadır (3). Gelişmiş ülkelerde yaş ilerlemesi ile ortaya çıkan kanserleşmede artış dikkat çekerken Sahra Altı Afrika ve Asya'daki birçok ülkede, yüksek oranda ölümcül kanserler genç yaşlarda tanı almaktadır (3). Bray ve ark., International Agency for Research on Cancer (IARC)'ın dünyanın 20 coğrafik bölgesinde oluşturduğu GLOBACAN 2018 Kanser insidansı tahminlerini bir makalede toplamışlardır. Buna göre 2018 yılında; nonmelanom cilt kanserleri hariç olmak üzere 17 milyon yeni kanser olgusu ve 9,5 milyon kansere bağlı ölüm saptanmıştır. Her iki cins bir arada değerlendirildiğinde insidansta ve kansere bağlı ölümlerde akciğer kanseri birinci sıradadır (2). Fitzmaurice ve ark.'nın 195 ülkede, 32 kanser araştırdıkları global kanser kollaborasyonuna göre 2005-2015 arası 10 yıllık periyotta kanser insidansı \%33 oranında artış göstermiştir (1). Buna \%16 populasyon yaşlanması, \%13 populasyon artışı ve $\% 4$ yaşa spesifik değişiklikler katkıda bulunmuştur. Bu çalışmacılar da erkeklerde kanser ölümlerinde birinci sırada trakea, bronş ve akciğer kanseri, kadınlarda ise meme kanserini bulmuşlardır. Amerikan kanser istatistiklerinde Erkeklerde en sık görülen ilk üç kanser sırasıyla prostat, akciğer ve kolorektal kanserler iken mortalite sıklığında bu sıralama akciğer, prostat ve kolorektal olarak değişmektedir. Kadınlarda ise insidans sıralaması meme akciğer ve kolorektal kanserler iken mortalite sıklığında akciğer öne geçmekte, bunu meme ve kolorektal kanser izlemektedir (4).

Bizim ülkemizde T.C. Sağlık Bakanlığı, Türkiye Halk Sağlığı Kurumu, Kanser Savaş Daire Başkanlığının yayınladığı Türkiye Kanser İstatistiklerine göre de global sonuçlara uygun oranlar bulunmuştur. Erkeklerde kanser insidansında akciğer kanserleri birinci sıradadır. Bunu prostat ve kolorektal kanserler izlemektedir. Kadınlarda ise meme kanseri birinci sırada olup bunu tiroit ve kolorektal kanserler izlemektedir (5).

$\mathrm{Bu}$ çalışmada; Ege Üniversitesi Hastanesi veri tabanındaki kanser olgularının epidemiyolojik ve genel sağ kalım özelliklerini istatistiksel açıdan değerlendirilmesi ve sonuçların dünya ve Türkiye kanser istatistikleri ile karşılaştırılması hedeflenmiş olup etik kurul onayı alınarak yayınlanmaktadır.

\section{Gereç ve Yöntem}

T.C. Sağlık Bakanlığı, Ege Üniversitesi (EÜ) ve Boston Massachusetts Üniversitesi arasında kanser verisi toplanması için yapılan ortak protokol 
sonrası Türkiye'de ilk kez aktif kanser kayıtçılığı Ege Üniversitesi Kanser Araştırma Merkezi (EÜKAM) tarafından 1992'de başlatılmıştır. CANREG özel bilgisayar programına kaydedilen veriler DSÖ ve SEER sistemleri temelinde gruplanarak analizler yapılmıştır. İstatistik analizlerde Ki-kare, General Linear Model (GLM), Kaplan Meier sağ kalım analizleri uygulanmıştır. Kaplan Meier sağ kalım analizinde Log Rank (Mantel-Cox), Breslow (Generalized Wilcoxon) ve Tarone-Ware istatistikleri kullanılmıştır. İstatistik analizlerde $p<0,05$ istatistiksel olarak anlamlı kabul edilmiştir.

\section{Bulgular}

EÜKAM tarafından 1992-2017 arasında, 25 yıl içerisinde 117139 kanser kaydı yapılmış olup bu çalışmada, cilt kanserleri hariç, 107238 kanser verisi esas alınmıştır. Olguların \%52,8'i erkek, \%47,8'i kadındır (Şekil-1).

\section{Cinsiyete Göre Dağılım}

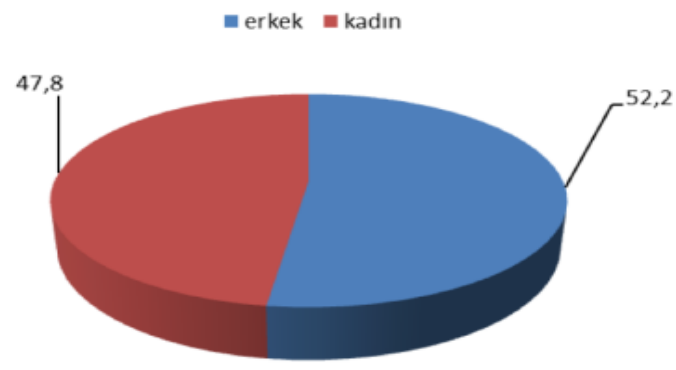

Şekil-1. Cinsiyete göre dağılım grafiği.
Olguların yaş ortalaması $54,87 \pm 0,62$ olup erkeklerde 60-69 yaş grubunda, kadınlarda ise 50-59 yaş grubunda en sık görülmektedir $(p<0,0001) \quad$ (Şekil-2). Olgularımızda sistemlere göre en fazla gastrointestinal sistem (GIS) tümörleri görülmektedir. Bunu baş boyun kanserleri ve solunum sistemi kanserleri izlemektedir. Cinsiyete göre sistem kanserlerinde ise erkeklerde solunum sistemi, kadınlarda ise meme kanseri ilk sırayı almaktadır (Tablo-1, Şekil-3).

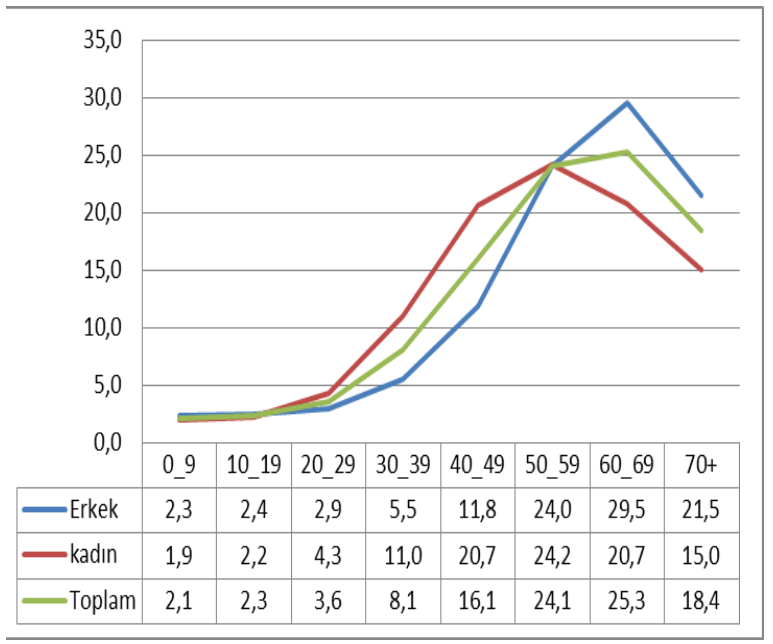

Şekil-2. Cinsiyete ve yaş dağılımına göre kanserlerin grafiği.

Tablo-1. Sistemlere ve cinsiyete göre dağılım.

\begin{tabular}{|c|c|c|c|c|c|c|}
\hline \multirow{2}{*}{ Sistemlere Göre Dağılım } & \multicolumn{2}{|c|}{ Erkek } & \multicolumn{2}{|c|}{ Kadın } & \multicolumn{2}{|c|}{ Toplam } \\
\hline & $\mathbf{n}$ & $\%$ & $\mathbf{n}$ & $\%$ & $\mathbf{n}$ & $\%$ \\
\hline Gis & 11923 & 21,3 & 7619 & 14,9 & 19542 & 18,2 \\
\hline Baş ve Boyun & 7225 & 12,9 & 8176 & 15,9 & 15401 & 14,4 \\
\hline Solunum sistemi & 12507 & 22,4 & 1745 & 3,4 & 14252 & 13,3 \\
\hline Meme & 170 & 0,3 & 12909 & 25,2 & 13079 & 12,2 \\
\hline Kadın genital & 0 & 0,0 & 8332 & 16,2 & 8332 & 7,8 \\
\hline Kan kemik iliği & 3739 & 6,7 & 2924 & 5,7 & 6663 & 6,2 \\
\hline Üriner sistem & 4744 & 8,5 & 1288 & 2,5 & 6032 & 5,6 \\
\hline MSS & 2949 & 5,3 & 2928 & 5,7 & 5877 & 5,5 \\
\hline Erkek genital & 5634 & 10,1 & 0 & 0,0 & 5634 & 5,3 \\
\hline Lenf sistemi & 2298 & 4,1 & 1623 & 3,2 & 3921 & 3,7 \\
\hline Primeri bilinmeyen & 2053 & 3,7 & 1397 & 2,7 & 3450 & 3,2 \\
\hline Nadir tümörler & 949 & 1,7 & 945 & 1,8 & 1894 & 1,8 \\
\hline Bağ Dokusu & 942 & 1,7 & 837 & 1,6 & 1779 & 1,7 \\
\hline Kemik eklem & 813 & 1,5 & 569 & 1,1 & 1382 & 1,3 \\
\hline Toplam & 55946 & 100,0 & 51292 & 100,0 & 107238 & 100,0 \\
\hline
\end{tabular}




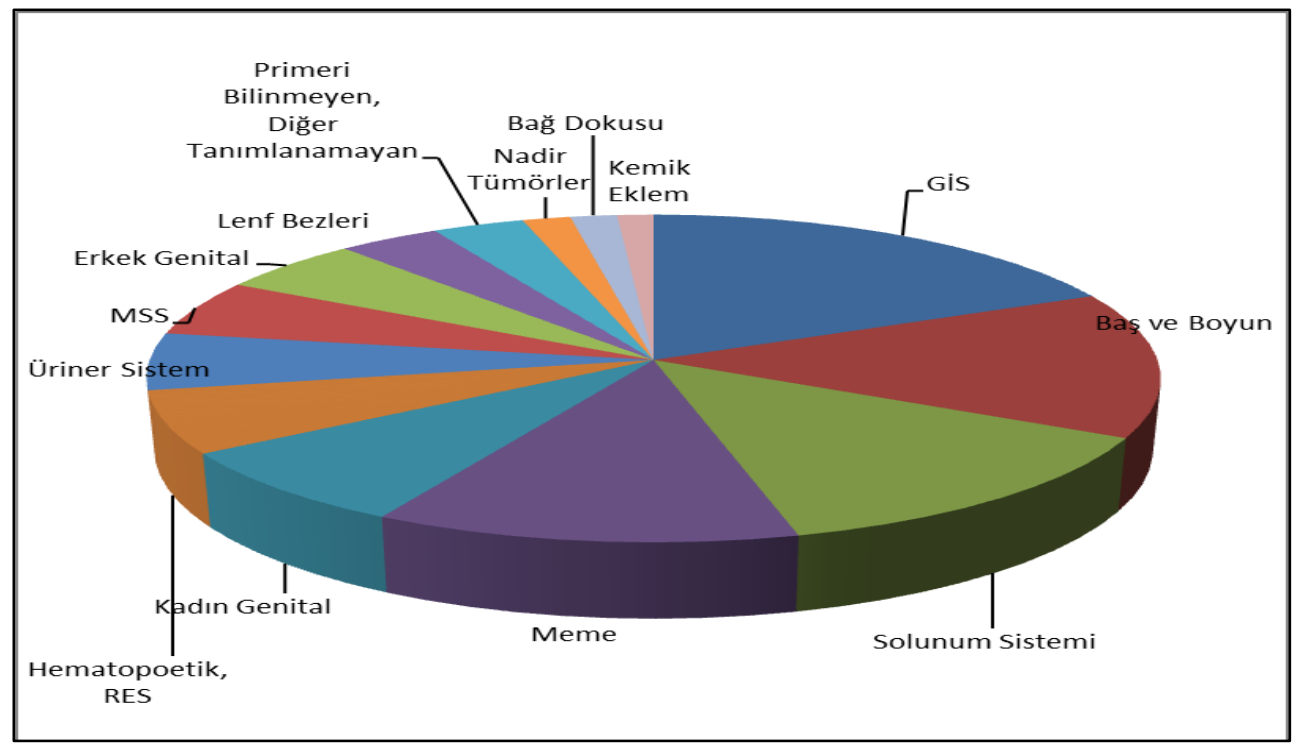

Şekil-3. Sistemlere göre dağılım grafiği.

Organ tutulumuna göre en sık görülen ilk 3 tümör akciğer, meme ve tiroit kanseridir. Kadınlarda sırasıyla en sık meme, tiroit ve korpus uteri, erkeklerde ise akciğer, prostat ve hematolojik kanserlerdir (Tablo-2).

Tablo-2. Organ tutulumuna ve cinsiyete göre en sık görülen kanserler.

\begin{tabular}{|c|c|c|c|c|c|c|c|c|}
\hline \multicolumn{3}{|c|}{ Erkek } & \multicolumn{3}{|c|}{ Kadın } & \multicolumn{3}{|c|}{ Toplam } \\
\hline Organ & $n$ & $\%$ & Organ & $n$ & $\%$ & Organ & $n$ & $\%$ \\
\hline Akciger & 12281 & 22,0 & Meme & 12942 & 25,2 & Akciğer & 13895 & 13,0 \\
\hline Prostat & 4772 & 8,5 & Troid & 6687 & 13,0 & Meme & 13154 & 12,3 \\
\hline $\begin{array}{l}\text { Kan,kemik iliği, } \\
\text { Hematopoetik S. }\end{array}$ & 3739 & 6,7 & Korpus Uteri & 3379 & 6,6 & Troid & 8450 & 7,9 \\
\hline Mesane & 3170 & 5,7 & $\begin{array}{l}\text { Kan,kemik iliği, } \\
\text { Hematopoetik S. }\end{array}$ & 2924 & 5,7 & $\begin{array}{l}\text { Kan,kemik iliği, } \\
\text { Hematopoetik S. }\end{array}$ & 6663 & 6,2 \\
\hline Larinks & 2991 & 5,3 & Serviks Uteri & 2647 & 5,2 & Prostat & 4783 & 4,5 \\
\hline Mide & 2692 & 4,8 & Ovaryum & 1771 & 3,5 & Mide & 4212 & 3,9 \\
\hline Kolon & 2444 & 4,4 & Kolon & 1718 & 3,3 & Kolon & 4162 & 3,9 \\
\hline Lenf Nodları & 2298 & 4,1 & Beyin & 1680 & 3,3 & Lenf Nodları & 3921 & 3,7 \\
\hline Beyin & 2227 & 4,0 & Lenf Nodları & 1623 & 3,2 & Beyin & 3907 & 3,6 \\
\hline
\end{tabular}

Yıllara ve organlara göre kanser görülme oranlarında doğrusal artış dikkat çekicidir ( $F=474,672$ $p<0,0001$ ) (Şekil-4). 


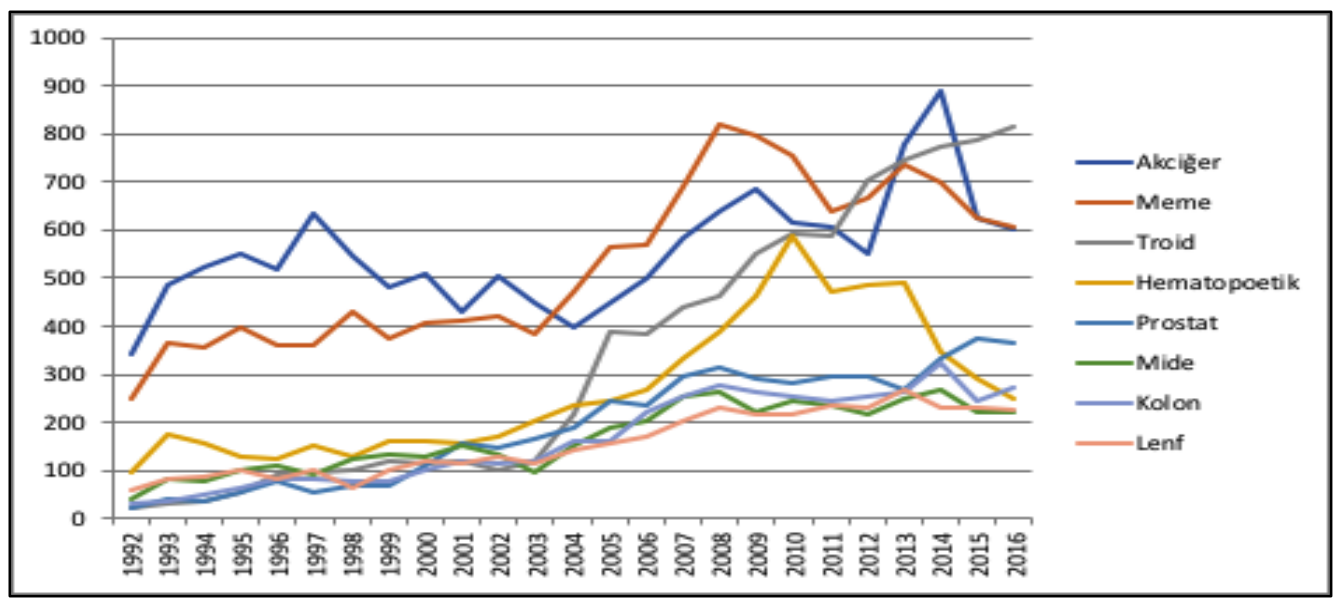

Şekil-4. Yıllara ve organ tutulumuna göre kanser artış eğilimi ( $F=474,672 p<0,0001)$.

Erişkin ve çocuk olgularımızın karşılaştırılması yapılmıştır. 20 yaş ve üstü erişkin, 19 yaş ve altı çocukluk çağı kabul edilerek baktığımızda olgularımızın \%4,5'i çocuk, \%95,5'i erişkindir (Tablo-3, Şekil-5).

Tablo-3. Yaşam dönemlerimize göre olgular.

\begin{tabular}{lll}
\hline Yaşam Dönemi & $\mathbf{n}$ & $\%$ \\
\hline Çocuk (0-19 y) & 4784 & 4,5 \\
Erişkin ( 2 20y) & 102454 & 95,5 \\
Toplam & $\mathbf{1 0 7 2 3 8}$ & $\mathbf{1 0 0 , 0}$ \\
\hline
\end{tabular}

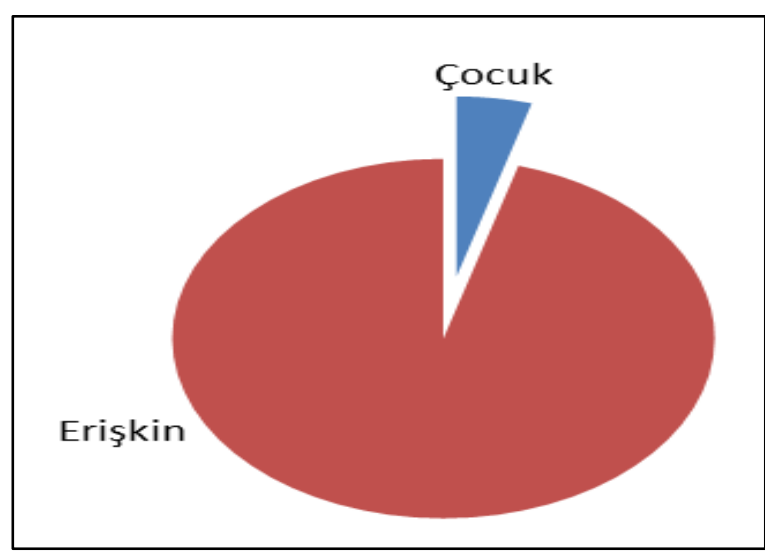

Şekil-5. Yaşam dönemlerine göre olgular.

Kadın olgular en fazla $(\% 41,8)$ lokal evrede tanı alırken, erkekler en fazla metastatik dönem-de $(\% 38,7)$ tanı almışlardır. Kadınlar anlamlı olarak daha erken evrede tanı almaktadır $(p<0,001)$. Tablo-4 'de evrelendirme yapılan olgularda tümör evrelerinin cinsiyete göre dağılımı görülmektedir (Tablo-4, Şekil-6).
Tablo-4. Tümör evrelerinin cinsiyete göre dağılım.

\begin{tabular}{lcccccc}
\hline & \multicolumn{2}{c}{ Erkek } & \multicolumn{2}{c}{ Kadın } & \multicolumn{2}{c}{ Toplam } \\
$\begin{array}{lcccccc}\text { Tanıda } \\
\text { Evre }\end{array}$ & $\mathbf{n}$ & $\%$ & $\mathbf{n}$ & $\%$ & $\mathbf{n}$ & $\%$ \\
\hline Insitu & 353 & 0,9 & 737 & 1,9 & 1090 & 1,4 \\
$\begin{array}{l}\text { Lokalize } \\
\text { Evre }\end{array}$ & 11916 & 30,8 & 15864 & 41,8 & 27780 & 36,2 \\
Lokal Illeri & 11451 & 29,6 & 12230 & 32,2 & 23681 & 30,9 \\
$\begin{array}{l}\text { Evre } \\
\text { Metastatik } \\
\text { Evre }\end{array}$ & 14967 & 38,7 & 9125 & 24 & 24092 & 31,4 \\
Toplam & 38687 & 100,0 & 37956 & 100,0 & 76643 & 100,0 \\
\hline
\end{tabular}

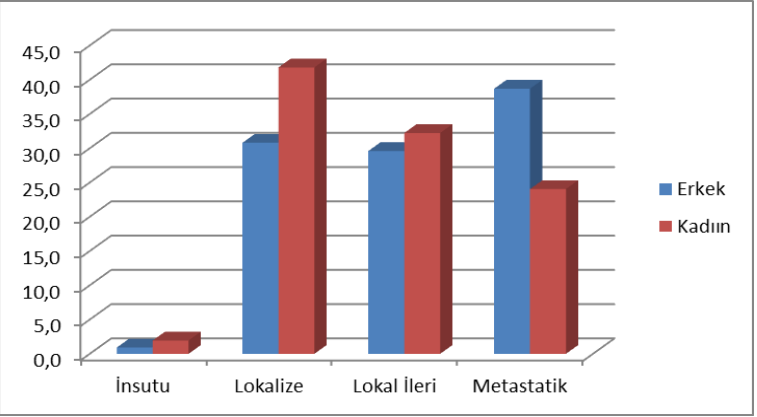

Şekil-6. Tümör evrelerinin cinsiyete göre dağılım grafiği.

Cinsiyetlere göre 10 yıllık GSK erkeklerde \%36,6, kadınlarda ise \%60,5 olup kadın olgularımızın daha uzun sağ kalıma sahip oldukları görülmüştür ( $p=0,0001)$ (Tablo-5). Şekil-7'de ise olguların cinsiyetlere göre sağ kalım eğrileri karşılaştırmalı olarak görülmektedir. 
Tablo-5. Olguların cinsiyetlere göre beş ve 10 yıllık genel sağ kalımların karşılaştırması.

\begin{tabular}{llllll}
\hline \multirow{2}{*}{ Cinsiyet } & $\mathrm{n}$ & Ölen & Yaşayan & & \\
& & $\mathrm{n}$ & $\%$ & $\mathrm{5}$ ıl & 10 Yıl \\
\hline Erkek & 37940 & 22542 & 40,6 & 47,1 & 36,6 \\
Kadın & 38994 & 14373 & 63,1 & 70 & 60,5 \\
\hline
\end{tabular}

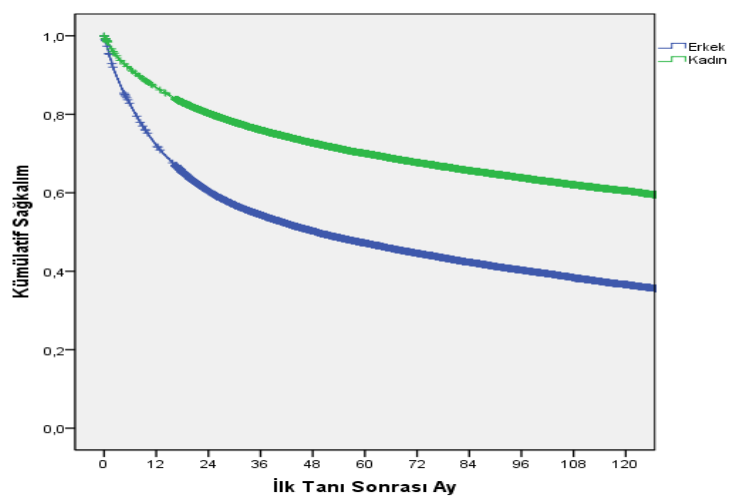

Şekil-7. Olguların cinsiyetlere göre sağ kalım eğrileri.

Erişkinlerde ve çocuklarda genel sağ kalım özellikleri karşılaştırıldığında çocukluk çağında sağ kalımların daha iyi olduğu dikkat çekicidir (Tablo-6, Resim-8).

Tablo-6. Erişkinlerde ve çocuklarda 2, 5 ve 10 yıllık genel sağ kalım karşılaştırması

\begin{tabular}{lcclllll}
\hline $\begin{array}{l}\text { Yaşam } \\
\text { Dönemleri }\end{array}$ & $\mathbf{n}$ & $\begin{array}{c}\text { Ölüm } \\
\mathbf{n}\end{array}$ & Yaşayan & $\mathbf{2}$ Yıl & $\mathbf{5}$ yıl & $\mathbf{1 0}$ Yıl \\
\hline $\begin{array}{l}\text { Çocuk } \\
\mathbf{0 - 1 9} \mathbf{y}\end{array}$ & 3320 & 885 & 73,3 & 84,2 & 76,6 & 72,0 \\
$\begin{array}{l}\text { Erişkin } \\
\mathbf{2 0} \mathbf{~}\end{array}$ & 73614 & 36030 & 51,1 & 69,8 & 57,9 & 47,6 \\
\hline
\end{tabular}

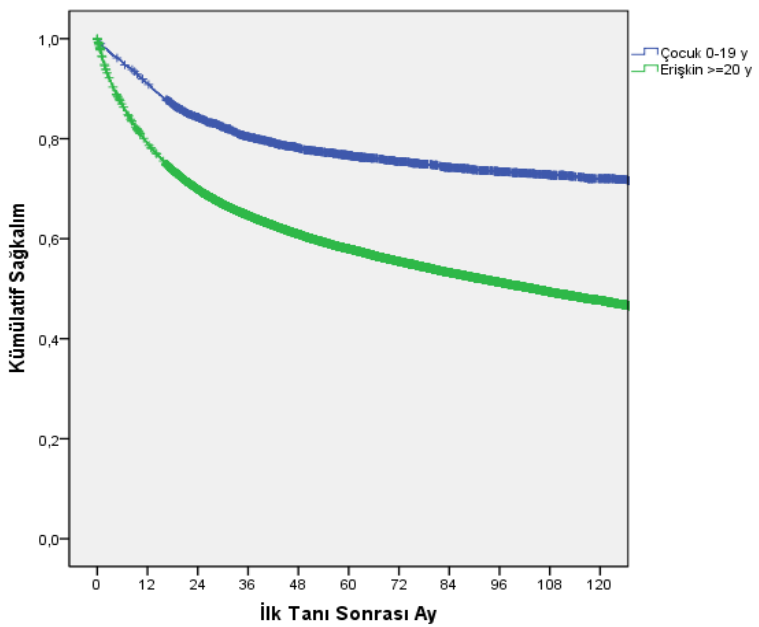

Şekil-8. Erişkinlerde ve çocuklarda genel sağ kalım eğrilerinin karşılaştırılması.

Sistemlere göre sağ kalımda içinde tiroit kanseri olan baş boyun kanserleri birinci sırdadır. Bunu meme kanseri izlemektedir (Tablo-7). En sık görülen İlk beş sisteme ait genel sağ kalım eğrilerinin karşılaştırılması Resim-9' da görülmektedir.

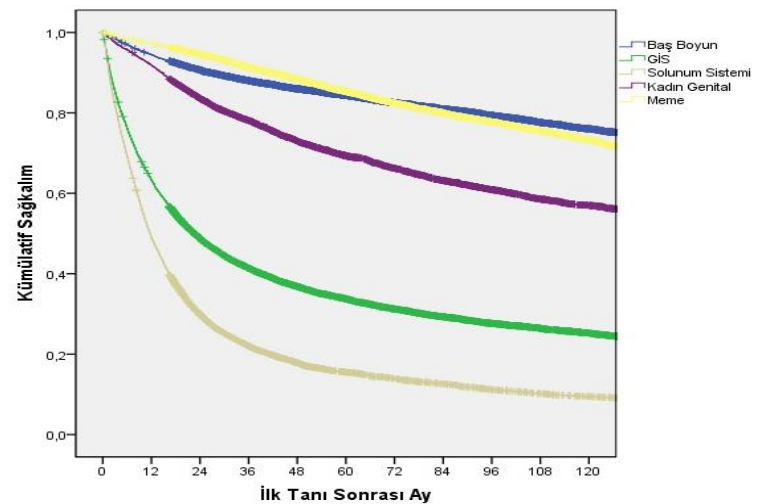

Şekil-9. En sık görülen İlk beş sisteme ait genel sağ kalım eğrileri

Tablo-7. Sistemlere göre 2, 5 ve 10 yıllık sağ kalımlar.

\begin{tabular}{lllllll}
\hline Sistemler & $\mathbf{n}$ & Ölüm $\mathbf{n}$ & Yaşayan & $\mathbf{2 ~ Y ı l}$ & $\mathbf{5}$ yıl & $\mathbf{1 0}$ Yıl \\
\hline Baş ve Boyun & 12251 & 2602 & 78,8 & 90,6 & 84,3 & 76,1 \\
GiS & 13783 & 9781 & 29,0 & 48,7 & 33,7 & 25,2 \\
Solunum sistemi & 7999 & 6945 & 13,2 & 29,8 & 15,5 & 9,5 \\
Kadın genital & 5712 & 2254 & 60,5 & 83,5 & 69,3 & 56,9 \\
Meme & 10335 & 2750 & 73,4 & 94,5 & 85,3 & 73,3 \\
Erkek genital & 4637 & 1613 & 65,2 & 88,0 & 75,9 & 59,0 \\
Üriner sistem & 4619 & 2258 & 51,1 & 73,3 & 59,4 & 46,5 \\
Lenf nodları & 2990 & 1069 & 64,2 & 79,2 & 70,2 & 61,1 \\
Kemik Eklem & 883 & 370 & 58,1 & 78,6 & 62,6 & 53,9 \\
Bağ Dokusu & 1231 & 589 & 52,2 & 75,3 & 58,4 & 47,8 \\
Hematopoetik, RES & 5126 & 2616 & 49,0 & 70,1 & 56,5 & 44,6 \\
MSS & 4023 & 1906 & 52,6 & 69,1 & 58,7 & 49,6 \\
Nadir tümörler & 1420 & 462 & 67,5 & 84,9 & 75,1 & 64,0 \\
Primeri bilinmeyen, diğer & 1925 & 1700 & 11,7 & 22,5 & 13,0 & 9,3 \\
\hline
\end{tabular}


Tablo-8. Sık görülen kanserlerin organlara göre genel sağ kalım özellikleri.

\begin{tabular}{ccccccc}
\hline Sistemler & $\mathbf{n}$ & Ölüm $\mathbf{n}$ & $\begin{array}{c}\text { Yaşayan } \\
\%\end{array}$ & $\mathbf{2}$ Yıl & $\mathbf{5}$ yıl & $\mathbf{1 0}$ Yıl \\
\hline Akciğer & 7814 & 6809 & 12,9 & 29,5 & 15,2 & 9,4 \\
Meme & 10335 & 2750 & 73,4 & 94,5 & 85,3 & 73,3 \\
Prostat & 3988 & 1503 & 62,3 & 87,5 & 74,2 & 55,2 \\
Tiroit & 7956 & 475 & 94,0 & 97,8 & 96,0 & 92,4 \\
Mide & 2881 & 2178 & 24,4 & 39,9 & 27,3 & 20,7 \\
Kolorektal & 5662 & 3102 & 45,2 & 72,4 & 53,1 & 40,3 \\
\hline
\end{tabular}

Organlara göre 10 yıllık GSK ise tiroit ve meme kanserlerinde $(\% 92,4$ ve $\% 73,3)$ daha iyi, akciğer kanserlerinde ise en kötü $(\% 9,4)$ olduğu görülmüştür $(p=0,0001)$ (Tablo-8, Şekil-10).

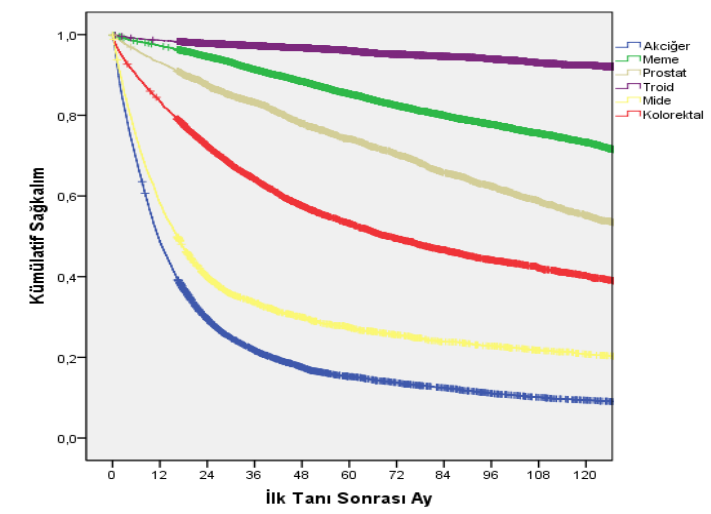

Şekil-10. Sık görülen kanserlerin organlara göre genel sağkalım özellikleri.

Genel sağkalım açısından en sık görülen kanserlerdeki sağkalımları her iki cinsiyette ayrı ele alacak olursak; erkeklerde en iyi prognoz gösteren kanser prostat kanseri olup bunu mesane kanseri ve hemapoetik sistem maligniteleri izlemektedir. Akciğer kanseri en kötü seyir göstermektedir (Şekil-11) (Log Rank (Mantel-Cox $)=5668,139 \mathrm{p}<0,0001)$. Kadınlarda ise en iyi sağkalım tiroit kanserlerindedir. Bunu meme ve korpus kanserleri izlemektedir. En kötü seyir ise over kanserindedir (Şekil-12) (Log Rank (Mantel-Cox) $=2986,981 \mathrm{p}<0,0001)$.

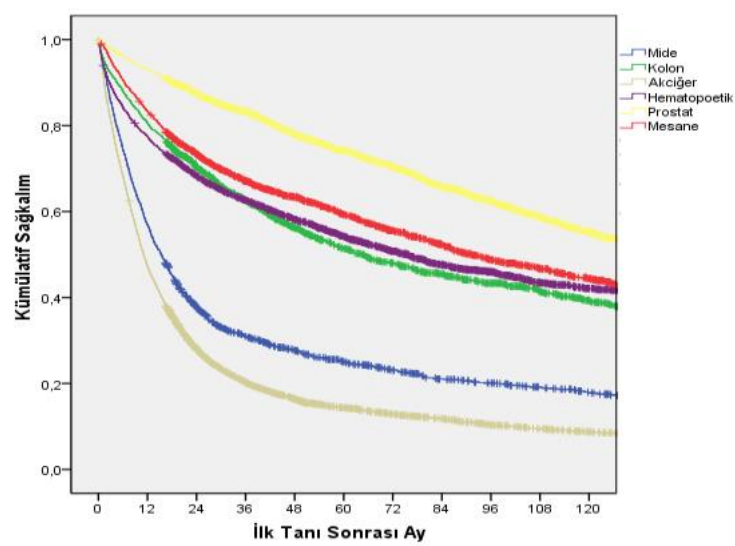

Şekil-11.Erkeklerde sık görülen kanserlerin organlara göre genel sağ kalım

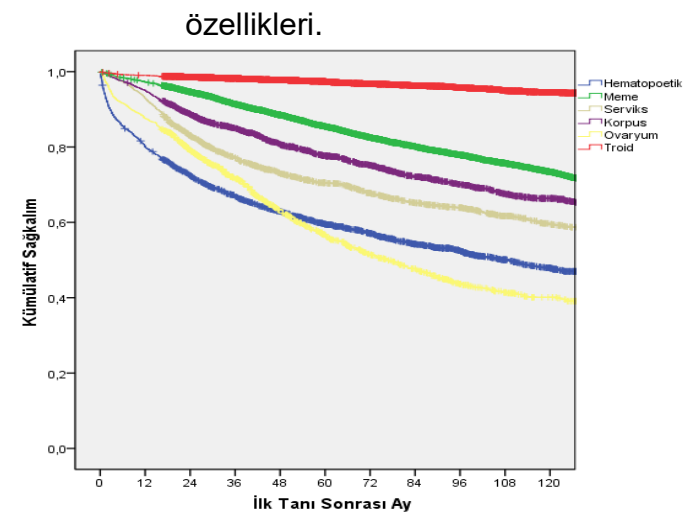

Şekil-12. Kadınlarda sık görülen kanserlerin organlara göre genel sağkalım özellikleri.

Her iki cinsiyeti mortalite açısından karşılaştırdığımızda erkeklerde en ölümcül kanser aynı zamanda en sık görülen kanser olan akciğer kanseri olduğu görülmektedir. Erkek kanserli olgularımızın \%25' akciğer kanserinden kaybedilmektedir (Şekil-13). Kadınlarda ise ölüm oranlarında birinci sırada kadınların en sık görülen kanseri olan meme kanseridir. Kadın kanserli olgularımızın \%18'i meme kanserinden kaybedilmektedir (Şekil-14).

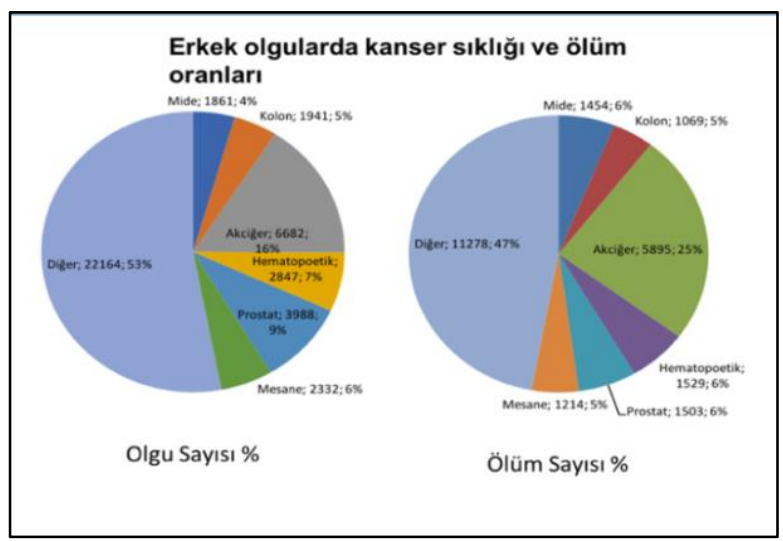

Şekil-13. Erkek olgularda kanser görülme sıklığı ve ölüm oranları. 


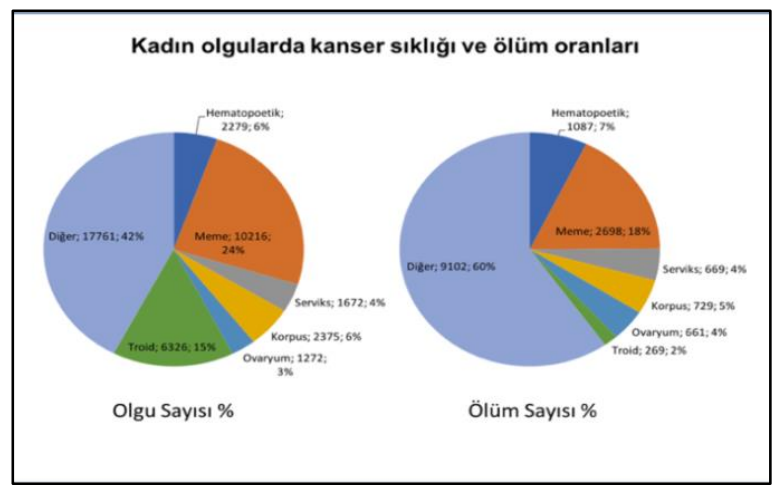

Şekil-14. Kadın olgularda kanser görülme sıklığı ve ölüm oranları.

\section{Tartışma}

EÜ Hastanesi veri tabanına kanser kayıtları 1992 de başlamış, 25 yıl içerisinde 117139 kanser olgusu kaydedilmiştir. Bu tek hastane olarak Türkiye'deki en geniş kanser serisidir. Genel kanser istatistiklerimizi global verilerle karşılaştırabilmek için non melanom cilt kanserleri hariç tutulmuştur $(2,3)$. Bu nedenle çalışma içine cilt kanserleri hariç 107238 kanser verisi esas alınmıştır. Olguların \%52,8'i erkek, \%47,8'i kadın olup erkek olgularda hafif bir sayısal üstünlük vardır.

Tüm global istatistiklerde kanser insidansında yıllara göre bir artış olduğu belirtilmektedir (1-4, 6, 8). Fitzmaurice ve ark.'nın global kanser kolleborasyonuna göre 2005-2015 arası 10 yıllık periyotta kanser insidansı \%33 oranında artış göstermiştir (1). Buna \%16 popülasyon yaşlanması, $\% 13$ popülasyon artışı ve $\% 4$ yaşa spesifik değişiklikler katkıda bulunmuştur. Ege Üniversitesi hastanesi kanser kayıtlarında da global kanser insidansında artışa paralel olarak artış olduğu görülmektedir. Yıllara ve organlara göre kanser görülme oranlarında yıllara göre doğrusal artış dikkat çekici olup en fazla artışın tiroit, akciğer ve meme kanserinde olduğu görülmüştür ( $F=474,672 ; p<0,0001)$.

Her iki cinsiyet için en fazla görülen kanser GLOBOCAN 2018 verilerine göre total vakaların $\% 11,6$ 'sını oluşturan solunum sistemi kanserleridir (2). Bu kanser tüm kanser ölümlerinin \%18,4'ünü oluşturur. Bizim erkek olgularımızda en sık görülen kanser trakea, bronş ve akciğer kanserini kapsayan solunum sistemi kanserleri olmakla beraber her iki cinsiyeti ele alacak olursak en sık görülen kanserler gastrointestinal sistem (GIS) kanserleridir.

Organlara ve cinsiyete göre kanser sıklığında
GLOBOCAN 2018 çalışmasında erkeklerde en sık akciğer kanseri olup bunu prostat ve kolorektal kanserler izlemektedir. T.C. Sağlık Bakanlığı, Türkiye Halk Sağlığı Kurumu, Kanser Savaş Daire Başkanlığının yayınladığı Türkiye Kanser İstatistiklerine göre de sonuçlar benzerdir (5). Bizim hastanemizde ise sıralama akciğer, prostat ve hematolojik kanserler olarak bulunmuştur. Bray'in çalışmasında kadınlar arasında meme kanseri en sık görülen ve en çok ölüme neden olan kanser meme kanseridir. Bunu kolorektal ve akciğer kanserleri izler (2). Türkiye verilerinde ise meme kanserini tiroit ve kolorektal kanserler izlemektedir (5). Hastanemiz verilerine göre ise kadınlarda organlara göre en sık görülen kanserler sırasıyla meme, tiroit ve korpus uteri kanseridir. Meme ve tiroit kanserlerinin görülüşü Türkiye ortalamasına benzer bulunmuştur.

Bray ve arkadaşlarının çalışmalarında her iki cins bir arada yerleşim yerlerine göre kanserleri mortalite açısından karşılaştırıldığında \%18,4 ile akciğer kanserini bulmuşlardır. Bunu mide ve karaciğer kanserleri, dördüncü sırada meme kanserleri izlemektedir (2). Feray ve arkadaşlarının Avrupa kanser insidansı ve mortalitesi çalışmasında kadın ve erkek olgular ayrı değerlendirilmiş, akciğer kanseri \% 24 ile mortalitede birinci sırada bulunmuştur. Siegel ve ark.'nın ABD'deki 2018 kanser istatistikleri çalışmasında ise erkeklerde mortalite sıklığında sıralamada \%26 ile akciğer kanseri birinci sıradadır. Bunu prostat, kolorektal, pankreas kanserleri izlemektedir (4). Bizim çalışmamızdaki erkek kanserleri mortalitesinde birinci sırada olan akciğer kanserlerinde bu oran \%25'tir. Erkek kanserlerimizin dörtte biri akciğer kanserinden kaybedilmektedir. Avrupa çalışmasında mortalite oranında akciğeri kolorektal, prostat ve pankreas kanserleri izlemektedir. Bizim çalışmamızda ise akciğeri mide, hemapoetik maligniteler ve prostat kanserleri izlemektedir. Avrupa çalışmasında kadınlarda kanser mortalitesinde \%16,2 ile meme kanseri birinci sıradadır. Bunu akciğer, kolorektal, ve pankreas kanseri izlemektedir (7). Siegel ve ark.'nın Amerika çalışmasında ise meme kanserini kadınlarda en sık görülen kanser olmakla beraber ölüme en çok neden olan kanserin akciğer kanseri olduğunu bulmuşlardır. Kanser mortalite sıklığında akciğeri meme, kolorektal, pankreas ve over kanserleri izlemektedir (4). Bizim kadın kanserli olgularımızda ise ölüme en sık sebebiyet veren meme kanseri \%18'lik bir yer kaplamaktadır. Bunu hemopoetik, maligniteler, korpus uteri, serviks uteri ve over kanseri gibi jinekolojik maligniteler izlemektedir. 
Olgularımızda her iki cinsiyeti 5 ve 10 yıllık sağ kalımlar açısından karşılaştırdığımızda (Tablo-5) sırasıyla erkeklerde \%47,1 ve \%36,6 iken kadınlarda $\% 70$ ve $\% 60,5$ bulunmuştur. Bizim serimizde kadın olgularda sağ kalımlar daha uzundur. Bunun nedeni erkeklerde en ölümcül olan akciğer kanserinin en sık görülmesi yanı sıra diğer sık görülen prostat ve kolorektal kanser gibi tarama yöntemleri ile kolayca erken saptanacak kanserlerin geç evrede yakalanmasının olduğu düşünülmüştür. Kadınlara yönelik farkındalık çalışmalarının yoğunluğuna, kadınların vücutları ile daha ilgili olmasına bağlı olarak kadınlar daha erken evrelerde doktora başvurmaktadırlar. Sık görülen olgularımız arasında en iyi sağ kalım tiroit kanserindedir. Beş ve 10 yıllık sağ kalımlar tiroit kanserinde \%96 ve \%92,4, meme kanserinde $\% 85,3$ ve $\% 73,3$, prostat kanserinde $\% 74,2$ ve $\% 55,2$ iken en kötü seyirli akciğer kanserinde $\% 15,2$ ve $\% 9,4$ dür (Tablo-8). Sonuçlarımız kaynaklarla uyumlu bulunmuştur.

\section{Sonuç}

Çalışmamızda erkeklerin kadınlara göre sayıca daha fazla ve daha ileri yaşlarda olduğu görülmüştür. Evrelere göre dağılımda ise kadınların erkeklere göre daha erken evrede tanı aldığı belirlenmiştir. On yıllık GSK'nin tiroit ve meme kanserinde daha iyi, Akciğer kanserlerinde ise en kötü olduğu görülmüştür. Olguların cinsiyetlere göre GSK'de kadınların daha uzun sağ kalıma sahip olmaları dikkat çekicidir. Prognozu en kötü kanserlerden biri olan akciğer kanserinin erkeklerde çok görülmesi ve birçok kanser türünde erkeklerin daha ileri evrelerde tanı alması kötü prognozda önemli bir rol oynar. Kadınlara yönelik etkin kanser farkındalık programları ve kadınların bedenleri ile daha ilgili olmaları erken tanı açısından bir avantaj oluşturmaktadır. Bu nedenle erkeklere yönelik kanser farkındalık çalışmalarının daha etkin yapılması gerektiğini düşünmekteyiz.

\section{Kaynaklar}

1. Fitzmaurice C, Allen C, Barber RM et al: Global, Regional, and National Cancer Incidence, Mortality, Years of Life Lost, Years Lived With Disability, and Disability-Adjusted Life-years for 32 Cancer Groups, 1990 to 2015 : A Systematic Analysis for the Global Burden of Disease Study. JAMA Oncol. 2017 Apr 1; 3 (4): 524-48.

2. Bray F, Ferlay J, Soerjomataram I and et al: Global Cancer Statistics 2018: GLOBOCAN Estimates of Incidence and Mortality Worldwide for 36 Cancers in 185 Countries . Cancer J Clin. 2018; 68: 394-424.

3. Jemal A, Vineis P, Bray F, Torre L, Forman D (Editörler). Kanser Atlası. İkinci Baskı. Atlanta, GA: Amerikan Kanser Derneği; 2014. www.cancer.org/canceratlas.

4. Siegel RL, Miller KD, Jemal A.CA. Cancer Statistics, 2018. CA CANCER J CLIN 2018; 68: 7-30.

5. Gültekin M, Boztaş G; Türkiye Kanser İstatistikleri. T.C. Sağlık Bakanlığı, Türkiye Halk Sağlığı Kurumu, Kanser Savaş Daire Başkanlığı. 2016.

6. Torre LA, Bray F, et al: Global cancer statistics, 2012. CA Cancer J Clin. 2015 Mar; 65 (2): 87-108.

7. Ferlay J, Steliarova-Foucher E, etal: Cancer incidence and mortality patterns in Europe: estimates for 40 countries in 2012. 2013 Apr; 49 (6): 1374-403. Epub 2013 Feb 26.

8. Ferlay J, Soerjomataram I, et al; Cancer incidence and mortality worldwide: sources, methods and major patterns in GLOBOCAN 2012. J Cancer. 2015 Mar 1; 136 (5): E359-86. 